\title{
Régine Borderie, Balzac peintre de corps. «La Comédie humaine» ou le sens du détail
}

\section{Marco Stupazzoni}

\section{Q OpenEdition}

1 Journals

\section{Edizione digitale}

URL: https://journals.openedition.org/studifrancesi/40908

DOI: 10.4000/studifrancesi.40908

ISSN: 2421-5856

\section{Editore}

Rosenberg \& Sellier

\section{Edizione cartacea}

Data di pubblicazione: 1 juillet 2004

Paginazione: 208

ISSN: 0039-2944

\section{Notizia bibliografica digitale}

Marco Stupazzoni, «Régine Borderie, Balzac peintre de corps. «La Comédie humaine» ou le sens du détail», Studi Francesi [Online], 142 (XLVIII | I) | 2004, online dal 30 novembre 2015, consultato il 09 septembre 2021. URL: http://journals.openedition.org/studifrancesi/40908 ; DOI: https://doi.org/ 10.4000/studifrancesi.40908

Questo documento è stato generato automaticamente il 9 septembre 2021.

\section{(c)}

Studi Francesi è distribuita con Licenza Creative Commons Attribuzione - Non commerciale - Non opere derivate 4.0 Internazionale. 


\title{
Régine Borderie, Balzac peintre de corps. «La Comédie humaine» ou le sens du détail
}

\author{
Marco Stupazzoni
}

\section{NOTIZIA}

RÉGINE BORDERIE, Balzac peintre de corps. «La Comédie humaine» ou le sens du détail, Paris, SEDES, 2002 («Collection du Bicentenaire»), pp. 243.

1 Questo interessante studio di Régine Borderie fa parte dell'ormai consolidata collana del «Bicentenaire» curata da Nicole Mozet per le edizioni Sedes.

2 Il volume si struttura in cinque parti integrate da un'introduzione, un'appendice (Annexe: perspective sur la rhétorique du portrait, pp. 215-220) e da un utile capitolo bibliografico.

3 L'oggetto privilegiato di questa pubblicazione riguarda l'analisi degli aspetti fisiologici, morali, storici, estetici e sociali della rappresentazione del corpo nella Comédie humaine. I fondamenti teorici della fisiognomica lavateriana costituiscono, per Balzac, il modello epistemologico su cui inscrivere il tempo storico e il tempo biografico dei suoi personaggi, al fine di moltiplicare gli orizzonti narrativi della propria opera. Balzac è consapevole di vivere in un'epoca fondamentalmente ibrida dal punto di vista sociale e il dettaglio fisiognomico gli consente di restituire, nella sua trasparente leggibilità, questa mescolanza di forme, di stili e di caratteri antropologici altrimenti indecifrabile.

Il principio di unità di composizione, sul quale lo scrittore intende fondare il proprio sistema letterario, implica una visione unitaria dell'uomo e della realtà, in cui l'interdipendenza tra mondo fisico e mondo morale (o spirituale) riveste un ruolo di primo piano per quel che riguarda le sue implicazioni estetiche (la resa romanzesca delle categorie del bello e del brutto), storiche e retoriche. Balzac, scrive l'A., «réagit donc aux mélanges qu'il constate dans son monde et reprouve par la pratique du 
mélange détaillé; ce faisant, il s'éloigne doublement des conventions littéraires héritées de la rhétorique /.../ soucieuse de préserver les hiérarchies de styles et de genres» (p. 211).

5 Nella Comédie humaine, Balzac riconsidera i complessi rapporti tra fisiognomica e retorica sulla base di una nuova concezione del personaggio visto e rappresentato anzitutto come individuo: «la fiction énonce le singulier» (p. 212) e la crisi di identità propria dell'uomo suo contemporaneo viene ripensata alla luce di una diversa concezione della creatura narrativa, di cui Balzac preserva l'identità, ma senza, per questo, nascondere la sua intensa e drammatica problematicità. 